\title{
Japan's International Standards of Waste Recycling Treatment: Disseminating the Osaki System in Depok and Bali
}

\author{
Purnamawati \\ Osaki Town Government, Kagoshima Prefecture, Japan \\ <purnamawati.puru.ipur@gmail.com>
}

\begin{abstract}
This research explains the importance of approach and coordination from the Osaki Town government on waste recycling management of Osaki System to the community residents and companies, for changing their mindset on responsibilities and duties. This was done since the beginning when Osaki system was created until it becomes a sustainable system in daily life. The important key aspects on implementing the Osaki system are good cooperation and bond of trust shared among the government, community residents and companies. Osaki Town has achieved no.1 in the highest rate of waste resource recycling for 12 consecutive years in all of Japan. The system has made Osaki Town to become a SDGs system model in Japan, after receiving SDGs award from the Japanese government in December 2019. The Osaki System has succeeded to solve problems on reducing the volume of waste in landfill site. Being a sustainable waste resource recycling system and a model not only in Japan but also abroad, Osaki Town then disseminates the Osaki System in Indonesia which has the same problems, such as approach and cooperation between the government and the residents, reduce the waste volume in landfill areas by separate waste method for recycling and low cost management.
\end{abstract}

Keywords: separate waste management, Osaki System for resource recycling, sustainable system

\section{Introduction}

Osaki Town has the same problem with other places in Japan on the increased volume of waste entering the landfill site in 1990.[1] The town government made an approach to community resident and companies to change the mindset of separating the 
multiple waste items from home, with responsibilities and duties for obeying the rule of resource recycling of Osaki system.

The community residents and companies are equally involved, being responsible for finding solutions to the waste problem in their environment. The main purpose of Osaki System is to reduce the volume of waste entering the landfill by extending the life of landfill site through a method of separating the waste from the home/restaurant/ office as the recycling resources. Osaki Town manages the Osaki System as a sustainable resource recycling system at low cost.

Osaki Town's success in managing it as a sustainable system is because of the understanding, cooperation, collaboration and trust that are built among the government, residents and companies for implementing the waste recycling management of Osaki System that can extend the life of landfill site. Each of them is fully recognized their own respective roles.

The Osaki System has made the town rich in natural environment, economy, organic agriculture, livestock, social welfare, work opportunity and others. Because of this sustainable system, Osaki Town achieved 17 goal items of SDGs people's daily life. For that, Osaki Town received a SDGs Award from the Japan Government in 2019.
Having the experience and knowledge on waste management of Osaki System for resource recycling, Osaki Town disseminating the Osaki System in Indonesia, by providing some guidance and, training in Depok City, and then province of Jakarta and Bali in 2020. The issues for implementing the Osaki System to become a sustainable system in the model area of Indonesia are cooperation from all parties especially from community residents, recycling facilities and composting facilities.

\section{Implementation of the Osaki System as a Sustainable System}

\section{Collaboration and Trust between}

\section{Government and Residents}

In 1990, Osaki Town had to solve a waste volume problem.[1],[5],[6],[7] The town needed to have a method to reduce the waste volume entering the landfill site. Otherwise, the landfill could only functions for 5 years. [19],[24],[26] As the government, Osaki Town must change the mindset of residents to separate the waste from home, including companies also. It was not simple, but if this problem cannot be solved, then Osaki Town could lose its natural environment and also natural product from agriculture, farm and livestock.

In the beginning, the Osaki Town government made an approach to community resident by showing the real problem if the landfill was in full 
capacity. Osaki Town gave three choices of strategy plan for solving the landfill site problem:[8],[40],[24],[25]

1. Building an incinerator facility: The risk from this strategy is that government must building a new incinerator facility on a large area of land, using big budget from tax fund, expensive operational cost and must get approval from resident and congressmen. This strategy choice was rejected by all residents because they were afraid of their land and tax fund mostly will be taken for constructing and operating the incinerator facility.

2. Building a new landfill site: The risk from this strategy is to find a large area for the new landfill site, make new budget plan from tax and approval from residents and congressman. This strategy choice was rejected also by all residents because they were afraid to live nearby the new landfill site.

3. Extend the life of existing landfill:

The risk from this strategy is to change the mindset of residents and business companies about sorting and separating the waste. The idea was to extend the life and function of the existing landfill by separating the waste from home/office/restaurants, bring it to the community waste station, then end up in the recycling facilities. The separate waste of Osaki system is "If you mix the waste, it is just a waste, but if you separate the waste, it will be a valuable resource."

Before giving the three choices of strategy plan, Osaki Town government explained to community leaders what was the problem and see directly the condition of waste in the landfill area. After the community leaders saw the big problem, they understood and chose the plan to extend life of existing landfill without incinerator facility. [3],[8],[9]

To implement the separate waste management in Osaki daily life, there are steps in building coordination and trust bond between the government employee and residents[3],[8],[9],[39]

1. First step is to make the government employees understand how to solve the landfill site problem by seeing the landfill condition and how to use the method of sorting and separating the waste management of Osaki system, from home/office/restaurant/ companies/hotel. The town government must create leaders from inside the government as instructors. Osaki Town creates instructors from all parts of the government offices and trains all employees until now.

2. Second step is to cooperate with community leaders to learn the importance of cooperation from residents in applying the method of sorting and separate waste from home into the station.

Government built a trust bond with residents by giving the chance 


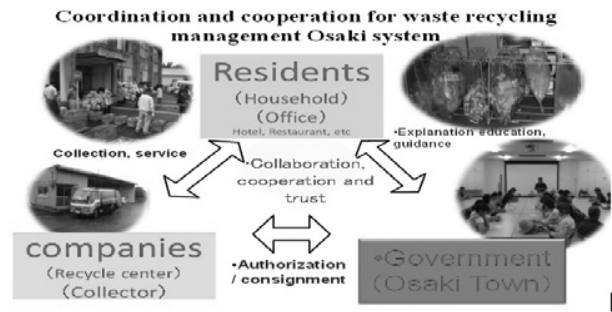

Fig. 1. Image of coordination, cooperation, responsibility and duties among the government, resident, facility company to follow the rule of waste management of Osaki System.[24], [25], [26]

for community leader to make their own rules within the community and to create the Hygiene Community Resident Association. This association has duty for monitoring, controlling, checking, training, and giving instruction to community resident. Community leaders get the chance to decide on schedule and station area. Osaki Town and Hygiene Community Resident Association leader worked together to create instructors from the residents for controlling and monitoring the implementation of Osaki system every year. [3],[8],[9]
Osaki Town has rules in implementing the waste management of Osaki System for residents and companies. Government, residents and companies have their own duty to implement the system all the way to the recycle center facilities, composting center and the landfill site of Osaki Town. All parties have the same duties to separate the waste from home/office/ restaurant/place by 28 waste items. Collecting day schedule and location for collecting is decided by government, community residents and companies, making all parties have responsible to obey their internal rule made inside their environment.[24]

In 1998 when the Osaki Town Government created the Osaki System, it started with 3 waste items to sort and separate from home. Having cooperation with community leaders and companies, the separate waste items continue to multiply every year. Osaki System has become a sustainable system until now. Osaki Town can

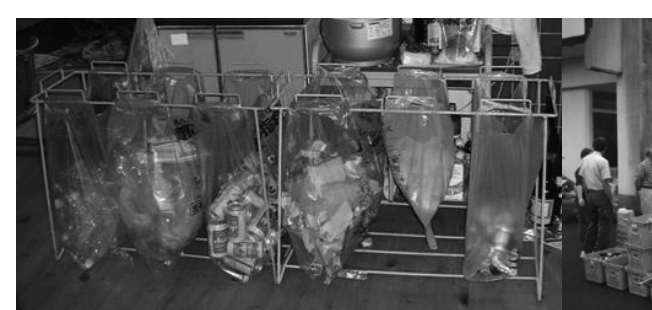

(a)

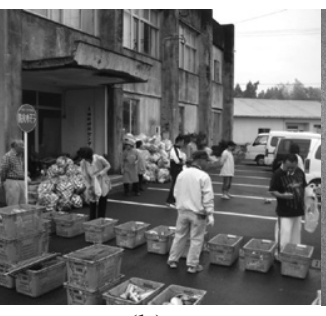

(b)

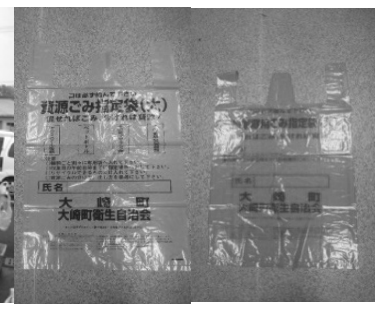

(c)

(d)

Fig. 2. Osaki Town government employees and community leader stand together to give explanation and training to residents as they bring separate waste from the home to the station. [24],[25],[26]. (a) Community residents have responsibility to go to the designated waste station (b), and make internal rules inside the community residents to obey the Osaki System rules. Pink plastic (c) is for pet bottles, PE, multiple plastics, multiple papers, etc.(c) Blue plastic is for waste that cannot be a recycle resource. (d) 


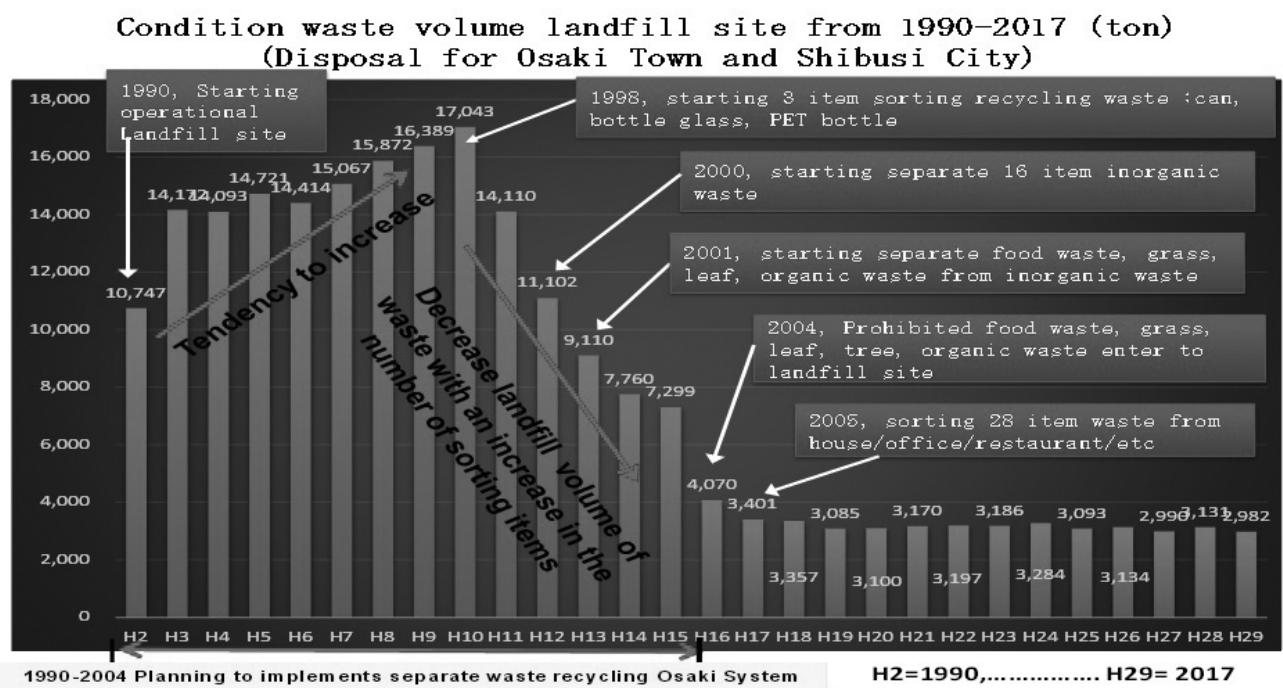

Fig. 3. Graphic explains about the increasing volume of waste entering the landfill site in Osaki Town from 1990. After the waste management of Osaki System started in 1998, the waste volume entering the landfill site is then decreasing. In 2004, Osaki Town started the Osaki System in recycling food waste to be processed for organic compost. This system makes the waste volume entering the landfill site even more decreased, because nearly $60 \%$ of waste volume is from food and organic waste. The method to separate the waste by types makes the landfill site more functioning and its life has extended. $[25],[26]$

reduce $83.1 \%$ of recycling resource entering the landfill for the first 12 years and continues to increase every year. [16],[17],[25],[26]

\section{Result of Sustainable Waste Recycling Management of Osaki System}

Osaki Town does not have an incinerator facility. Therefore the Government still continues to use the Osaki System as a sustainable system in the Osaki people daily life. The result, Osaki Town is heading toward the international standard after receiving a SDGs Awards from the Japanese government in December 2019 due to its advantages.[27]

The advantages of Osaki System
[16],[24],[25],[26],[27]

1. Reduced the waste volume in landfill site. The landfill waste volume from 1990 to 2018 , which has decreased by $83.1 \%$ because of the waste recycling increase activity every year. In 1998 the landfill waste volume was 4,382 tons, but as people in Osaki Town implemented the sorting and separating waste from home every year, the landfill waste volume decreased to 670 tons by 2019.

2. Low cost on waste disposal management. Osaki Town may extend the life of landfill site for 35-45 more years, as a result of the waste volume that has decreased by 
$83.1 \%$. The landfill site looks clean and does not smell bad, due to the food waste that is not entering the landfill, whereas only $10 \%-15 \%$ volume of waste that is now entering the site.

3. Government saves up waste disposal management budget funds. Osaki Town can cut big on waste management cost per person and make recycling resource volume increase to $83.1 \%$ (based on calculated cost per person).

4. The profit from recycling returns to the government to be reused on welfare for the community and economy of Osaki Town.

5. Development of human resources and employment. Two recycle center facilities of Osaki employs and develops human resource in waste recycling management of Osaki System.

Community residents deliberately obey the rules of Osaki System that have been made by Osaki Town government. Community residents are already accustomed to carrying out sorted and separated waste for the continuity life of the people and to protect the natural environment. Osaki Town is rich in natural products, environment, agricultural, farm and livestock which all depend on clean natural environment conditions.[8],[39]

The town government and community residents have continued to strive for many more years to implement the sorting and separating waste into recycled resource. Therefore, the Japanese Environment Minister gave an award every year to Osaki Town as a town that produces the highest rate of waste recycling in all Japan and low cost in waste management. Osaki Town government appreciates the cooperation and coordination from its community residents for obeying the waste recycling management of Osaki System as the residents made their own rules in the community to obey this Osaki System.

\section{Coordination with Communities to}

\section{Implement the Osaki System}

With the existence of Hygiene Community Resident Association, the community residents and the Osaki Town government now have a commitment to both run the Osaki System. Consequently, the Hygiene Community Residents Association made internal rules and policies about duties and responsibilities on following the rules of Osaki System is to be carried out by all community residents. So the residents who made the internal rules and policies are the ones having the responsibility to implement the Osaki System rules in the community. [3],[8],[9]

The rules and policies of the Hygiene Community Resident Association are obligating residents throughout the Osaki Town to implement the sorting and separating the waste of Osaki System from 
home, to provide an educational training to residents on collecting and bringing out waste to the station and to determines which stations and who gets the duty within the community to monitor and check at the station when residents bringing the separated waste from home. So every resident has a responsibility to monitor and check for any mistake happened in the sorting and separating of collected waste from home.[3],[8],[9]

The most important responsibility of the Hygiene Community Resident Association is to provide an input and advice to the Osaki government on how to make it easier for residents to sort, separate and collecting the waste, which waste station to go to and what time and day is it to take out the waste from the home. The residents made the decision based on the conditions within the community. Afterward they discussed it with the town government and the recycle center facilities, so the rules and policies can be made together for the Osaki system to be implemented in all communities of Osaki Town. [24],[26],[36].

The way of the Hygiene Community Resident Association worked becomes an example to all Japan because of how its community residents has changed and willing to implement the Osaki System in their daily life. Community residents are aware of duties and responsibilities in their environment and help the government to solve the landfill site problem. The Hygiene Community Resident Association of Osaki Town has achieved an award from the Japanese Environment Minister in 2015, to be an example for every community residents in Japan.

\section{Osaki Town as a Model of SDGs}

The implementation of the waste management of Osaki System which has continued for many years in Osaki Town, reached no. 1 for the highest rate of waste resource recycling at $83.1 \%$ compared to other cities in Japan. Osaki Town has become an example for implementing the waste management operations by increasing the recycle waste materials from home, managing the profit gained from the selling of recycled product return to the resident's welfare and protecting the natural environment to stay clean and hygiene. Hence, Osaki Town has achieved an award from the Japanese government as an example of Sustainable Development Goals (SDGs) Japan on December $21^{\text {st }}$, 2018.[38],[25],[26]

The waste recycling of Osaki System makes the Osaki Town residents prosper in all fields. The outcome of this waste recycling system return to the resident's welfare benefit and the natural environment of Osaki Town are kept preserved. Osaki Town can take advantage of the waste recycle earnings for the benefit of Osaki Town people. The Osaki System has lasted for numerous years now and 
this sustainable system has gradually increasing its waste to produce more recycling resource so that Osaki Town's landfill can still function for 30-50 more years.[25],[26]

For that reason, the Japanese government sees the sustainable waste recycling management of Osaki System has succeeded in making the Osaki Town able to improve its social welfare and protects its natural environment for the benefit of the community residents. Moreover, the Japanese government also sees on the side of economy, organic agriculture, livestock, human resources, work opportunity, education and international relationship. Not to mention the partnership that Osaki Town has achieved on 12 items in the SDGs program for community welfare. Essentially, the Japanese government sees Osaki Town as an ideal model for the implementation of SDGs in Japan. [18],[2],[33],[35]

Osaki Town accomplishment on implementing the waste recycling management of Osaki System is because of the support from the community residents and the companies. The town government sustains to improve the Osaki system for the benefit of social welfare and to protect its natural environment for the next generation to come.

\section{Towards International Standards}

The experience of Osaki Town in managing waste into recycle resource using Osaki System, from 1998 to present, has made Osaki Town to become a pilot project in Japan and abroad.[34] Osaki Town supports the Indonesian government with its experience to solve the problems in reducing waste volume in landfill, through waste recycling management of Osaki system. [20],[21],[22],[23],[37]

The implementation of Osaki System in Indonesia is not easy, because of the difference in cultures, rules, systems and mindsets of how waste management becoming a recycle material that must be started at homes, offices, restaurants, hotel, etc. Osaki Town gives support to cities in Indonesia to have cooperation and collaboration for learning the experiences of how Osaki Town started the Osaki System from zero, in solving the problem of reducing waste entering the landfill for resource recycle. [28],[29],[30],[31],[32]

Osaki Town does not necessarily require the collaborating cities in Indonesia to equalize the implementation of Osaki System into their cities, but Osaki Town teaches the city government to create a similar system that can be applied in Indonesian cities by looking at the condition of residents, social culture, community and rules.

Thus, Osaki Town gives guidance and training to the city government of model areas in Indonesia to learn and practice the Osaki System in terms of rules, systems, laws, socialization, 
budgets, work plans, training to sort waste for recycle food waste for composting organic waste for recycling resource, making the sort and separate waste system, transportation method and system, making data reports, how to cooperate with residents, how to cooperate with recycle factory, how to make rules for company that manages the separate waste from hotel, restaurant and other places and for residents to obey the government rule in reducing waste volume entering the landfill site. [10],[11],[12],[13],[14],[15]

Osaki Town teaches and trains the collaborating cities about how it must make the Osaki System from scratch in 1998 , to be applicable to its residents so that it can be implemented up to now. Osaki Town teaches and provides practical training to government representatives, deputy of religious leaders, deputy of community leaders, deputy of youth leaders, mother community leader and congressmen to create a waste management system that can be implemented in Indonesia.[4], [28],[29],[30],[31],[32],[37]

In consequence, this new Osaki System of Indonesia can now be run in several collaborating cities of Indonesia that have learned the experiences from Osaki Town like in Bali Province (Klungkung prefecture, Denpasar city, Gianyar prefecture) and Depok City. In 2020, the second phase implementation of Osaki System can then be implemented in the provinces of Jakarta and Bali.[4],[37]

The problem of implementing the Osaki System in Indonesia is that hygiene community residents

\section{Research disseminating waste recycling Osaki system in Bali Province Model area : Denpasar, 75 householder, 285 population}

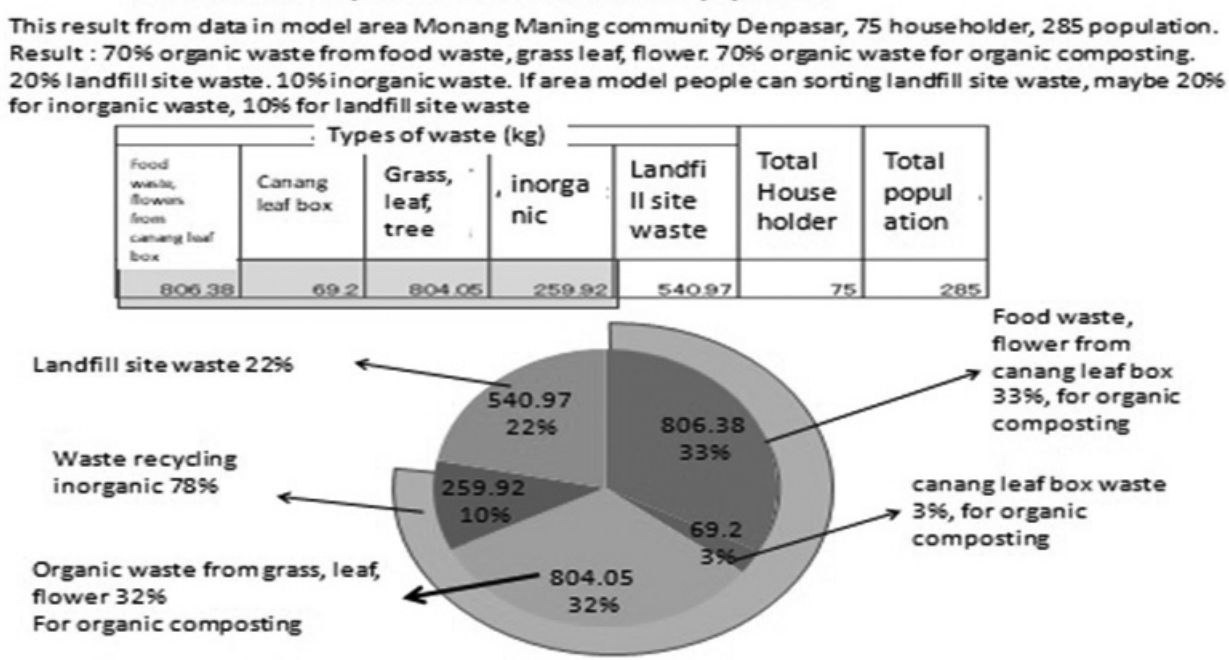

Fig. 4. Table data explained about Denpasar City area model of 75 homes with 285 populations for sorting and separating waste by types from home to the pick-up transportation.[28],[30],[31]. 
association has not been yet created like the Hygiene Community Residents Association in Osaki Town, and there is still a lack of composting facilities in accordance to the standard method of Osaki System. The important key to the sustainable waste recycling of Osaki System is cooperation among the government-community residents-companies, low cost on waste management and standardized system facilities. Therefore, the Osaki System in Indonesia will continue to improve if the facilities were available and the cooperation between the government and the residents could be established.

\section{Conclusions}

Osaki Town Government in 1990, as well as other cities in Japan and abroad, faced the same problem of full volume in the landfill site. To solve this, there are three options, first is to build an incinerator, second is to find a new landfill site and third which is the last option is for Osaki Town and community residents to sort and separate waste from home/restaurant/ office/companies for recycling resource. The main goal of sorting and separating waste in Osaki System is to reduce the volume of waste entering the landfill site. The waste separation is "if waste is mixed becomes garbage, if it is separated becomes recycle materials." As a result, there is only $10 \%-15 \%$ of waste entering the landfill site now.

The process of changing people's mindsets to do the sorting and separating waste by types was quite successful in Osaki Town, because of the cooperation and trust shared between the government and the community residents. Osaki Town has succeeded in making the community believe in this waste recycling management of Osaki System. The community residents together with the government have one goal, to reduce the volume of waste entering the landfill so there would be no new landfill or incinerator in their environment.

Osaki Town makes the separate rules and policy to regulate the implementation of Osaki System in the community, and the community has their internal rules and policy as well that regulates the implementation of Osaki System inside their community. Residents of community have a role, responsibility and obligation to obey the implementation of Osaki System. Osaki Town provides training and education to create leaders inside the community residents so they can give training and education to other residents for implementing the Osaki system in the community.

The waste recycling management of Osaki system develops the welfare for residents of Osaki Town, increases human resources, creates employment opportunities, improves the economy and income of the Osaki Town, protects the natural environment and increase the production of agricultural farm and 
livestock.

Osaki Town has been ranked no. 1 by the Japanese Minister of Environments for the highest rate of waste resource recycling as sustainable system in all Japan continuously for 12 years. The town can process $100 \%$ of waste to be $83.1 \%$ for recycle resource. Osaki Town became a model throughout Japan and abroad is also because cooperation all parties and low cost waste management in resource recycling.

Osaki System becomes an example throughout Japan because of its waste recycling management that has improved all sectors, people's lives and economy of Osaki Town. The town can prove that Osaki System is a sustainable waste recycling system inside the life of Osaki Town people. For that reason, Osaki Town has received an award from the Japanese government as a model of Japan's SDGs in December 2019. At this time, many local governments throughout Japan are learning the Osaki System in Osaki Town. Osaki Town furthermore gives support, knowledge and cooperation to other countries in sharing the experienced on reducing waste entering the landfill site with waste recycling management of Osaki system.

The result and development out of sustainable waste recycling of Osaki System has made the Osaki Town heading towards the international standard. Many other countries abroad are learning the experience of how Osaki Town implementing the Osaki System. Osaki Town is disseminating waste recycling management of Osaki System in various places of Indonesia that have the same problem in reducing waste volume in landfill site. Osaki Town provides experience, technology, methods and knowledge assistance to cities or provinces that has the cooperation with, such as Bali, Depok and Jakarta. Osaki Town does not require the same exact way for implementing the Osaki System in Indonesia, but it gives education, training and guidance to create a new waste recycling management system. And all this has to be implemented at low cost similarly to the waste recycling management of Osaki System.[]

\section{References}

[1] Amemiya, Takashi (2018). Current State and Trend of Waste and Recycling in Japan. Journal International Earth Environment Science 3;155

[2] Cosmo, Takagi (2020). Guide Book Practice of SDGs x Community Association Sustainable Development Goals 17 Goals to transform our world SDGs x Jichitai Jissen Gaido bukku. 1st edition. Gakuei Shuppansya, Japan.

[3] Fumiyo, Toya. Interviewed by writer (Oct 15th, 2018). History of implement separate waste recycling Osaki system from home and created association of community hygiene in community of Osaki Town 
[4] Jakarta Newspaper (September 2018). Japan offers cooperation on new recycling center "Osaki Town with Jakarta Province"

[5] Japan Environmental Sanitation Center (2013). Solid Waste Management and Recycling Technology of Japan - Toward a Sustainable Society. http://www.jesc.or.jp

[6] Japan Environmental Sanitation Center (2014). History and Current State of Waste Management in Japan. http://www.env.go.jp/recycle/circul/venous_industry/index.html

[7] Japan Industrial Waste Information Center (Nov 2018). Waste Management in Japan Rules and Figures. https://www.jwnet.or.jp/assets/pdf/en/20190322133536.pdf

[8] Katsuya, Tokurei. Interviewed by writer (2012-2019). History of separate waste recycling Osaki system, created waste recycling Osaki system in Osaki Town and crater for the first policy/rule/method/implement in Osaki system

[9] Koichi, Nakamura. Interviewed by writer (Aug 21st, 2018). Duty, cooperation, coordination association of community hygiene in community of Osaki Town as head of community hygiene association

[10] Minami Nihon Newspaper (2015/2/10). Waste Recycle Osaki System Program to abroadwaste recycling in Indonesia Program

[11] Minami Nihon Newspaper (2015/2/21). Osaki Town with Osaki system transform technol-ogy in Depok City

[12] Minami Nihon Newspaper (2015/2/22). Osaki Town with Osaki system trained model area worker for processing food waste to organic composting in Depok City

[13] Minami Nihon Newspaper (2016/9/9). Osaki Town made MOU cooperation with Bali province

[14] Minami Nihon Newspaper (2017/2/11). Osaki Town cooperation with Depok City for re-duce waste with waste recycling Osaki system

[15] Minami Nihon Newspaper (2017/3/16). Organic composting Osaki system progress in Bali Province

[16] Ministry of the Environment Minister's Secretariat. Waste Management and Recycling Department Waste Management Division. Waste Processing of Japan each year edition. http://www.env.go.jp/recycle/

[17] Ministry of the Environment Minister's Secretariat. Waste Management and Recycling De-partment Waste Management Division. http://www.env.go.jp/recycle/

[18] Norichika, Kanie (2020). Target to change Future-SDGs Idea Book. 12the edition. General incorporated association-Think the Earth, Japan

[19] Osaki Town (July 2014). Osaki Town toward to International with challenge reduce waste volume to landfill site with processing recycling waste-improve mindset "if you mix the waste, it is just waste, but if you separate the waste, it will be a valuable resource", Osaki Town PR Magazine 3

[20] Osaki Town Public Monthly Magazines (March 2017). Amazing Osaki Town "Sugoi Osaki cho.” Osaki Town Public Monthly Magazines, 2-7

[21] Osaki Town Resident Environment Section (2014). Transfer technology for waste disposal with Bali Province. Report of Hygiene Community Association of Osaki Town

[22] Osaki Town Resident Environment Section (2016). Report of Implement waste recycling Osaki system in area community of Depok City in JICA Program. Report of Osaki Town about Depok City JICA program

[23] Osaki Town Resident Environment Section (2017). Report of implement waste recycling osaki system in area community in Bali Province including organic farm. Report of Osaki 
Town about Bali Province JICA program

[24] Osaki Town Resident Environment Section (2018). if you mix the waste, it is just waste, but if you separate the waste, it will be a valuable resource. The guiding paper of waste article for trainer of Osaki Town.

[25] Osaki Town Resident Environment Section (2019). if you mix the waste, it is just waste, but if you separate the waste, it will be a valuable resource. The guiding paper of SDG's Osaki Town

[26] Osaki Town Resident Environment Section (March 2018). Initiative from Osaki Town as the highest rate waste recycling system No 1 in all Japan. International symposium Kyushu Branch of Japan Society of material cycles and waste management.

[27] Osaki Town. Garbage/Recycling/Environment. http://www.town.kagoshima-osaki.lg.jp/ so_densan/kurashi/gomi/index.html

[28] Purnamawati (2012, 2014, 2016, 2018, 2019). Guide manual report of Daily life in Osaki Town from 2011-now for implement sorting separate waste Osaki system from home until station for trainer Indonesia

[29] Purnamawati (2012-2016). Result JICA program in Depok City for implement waste recy-cling osaki system in community Depok City. Report for Osaki Town Resident Environment Section

[30] Purnamawati (2015-2017). Result JICA program in Bali Province for implement waste re-cycling osaki system in community in Klungkung Prefecture, Denpasar City, Gianyar Pre-fecture. Report for Osaki Town Resident Environment Section

[31] Purnamawati (2018). Development and dissemination of general waste treatment technology and international technical support of Osaki Town to model areas for association community sanitary in Depok City and Bali Province Indonesia. The 76th Annual Socio-logical Society of West Japan Conference 24. http://www2.lit.kyushu-u. ac.jp/ sociowest/img/sswj76.pdf

[32] Purnamawati (Oct 2nd, 2020). Osaki Town in Waste Recycling Treatment of Osaki System as Sustainable System towards the International Standards-Disseminating the Osaki System in the City of Depok and the Provinces of Bali and Jakarta. International Journal of 5th ICIIS - Future Cities of the World, Hindu Indonesia University. UNHI Press, 1250. ISBN 978-623-7963-23-3

[33] Shigeki, Mitomo; Koichi, Yokota; Kotono, Hara (2020). The Essence of SDGs. 1st edition. Choukeizai, Japan (2020)

[34] Tadashi, Yagi (2014). For Recycling of General Waste in Shibushi-shi and Osaki-cho (shibushishi - Osaki cho ni okeru ippan haikibutsu no risaikuru ni tsuite). Journal regional Studies International Kagoshima University 41(2), 27-43

[35] Takei, Fumio (December 2015). The highest rate waste recycling system No.1 in all Japan continue for every year, next step for Osaki Town to challenge disseminating eco system to abroad. Monthly article Zaikai Kyushu No. 1095

[36] Taro, Hagami (May 2020). Local Region does not disappear, Kagoshima Prefecture Osaki Town. The Bungeishunju. 372-376, Japan

[37] Tempo Newspaper (2018/9/19). TPST Pesanggarahan become model for Jakarta to waste recycling treatment-coordination with Osaki Town

[38] Yagi, Honshi. (October 2013). Processing food waste, organic waste to organic composting and cooking oil waste for recycling "Katei nama gomi no taihika, hasshoku youbura katsuyou mo", Monthly article waste, vol 39, N0,511

[39] Yasuhiro, Higashi. Interviewed by writer (2012, 2015, 2017). History of separate waste recycling Osaki system as government and mayor of Osaki Town 